\title{
THE INFLUENCE OF ORGANIC AMENDMENTS ON NUMBERS OF NEMATODES AND OTHER MICROORGANISMS IN THE SOIL
}

By

ARTHUR HARRIS TOMERLIN, JR.

\begin{abstract}
A DISSERTATION PRESENTED TO THE GRADUATE COUNCIL OF THE UNIVERSITY OF FLORIDA IN PARTIAL FULFILLMENT OF THE REQUIREMENTS FOR THE DEGREE OF DOCTOR OF PHILOSOPHY
\end{abstract}

UNIVERSITY OF FLORIDA

1969 


\section{ACKNOWLEDGMENTS}

The author expresses his sincerc appreciation to members of his supervisory committee: Dr. Grover C. Smart, Jr., Chairman, for his guidance, consultation, criticism, and, most of all, sincerity, in the course of his graduate studies; Dr. V. G. Perry for his timely help in preparing this manuscript; Dr. C. F. Eno and Dr. D. A. Roberts for reviewing and commenting on this dissertation.

Appreciation is extended to the U. S. D. A., Agricultural Research jervice, whose funds under Contract No. 12-14-100-8142(34) made this rescarch possible.

The author expresses his gratitutde and appreciation to his friend, Mr. R. W. Patrick, for his technical assistance on sevaral occasions.

And last, the author sincerely thanks his wife, Mircya, for her patience, encouragement, and understanding during the course of his graduate studies. 


\section{CONTENTS}

Page

ACKNOWLEDGMENTS ........................ . . . $\mathrm{i} \mathbf{i}$

LIST OF TABLES ........................ iv

LIST OF FIGURES..................... . . . . . . . . . .

INTRODUCTION AND LITERATURE REVIEW . . . . . . . . . . I

MATERIALS AND METHODS .......................... 4

RESULTS . . . . . . . . . . . . . . . . 8

SUMMARY AND CONCLUSIONS ............................. 31

APPENDIX ................................. 34

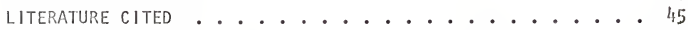

BIOGRAPHICAL SKETCH ............... 49 


\section{LIST OF TABLES}

Table

1. Average plant heights and weights and recovery of Belonolaimus longicaudatus and Mononchoides sp. nematodes eight weeks after inoculation into soil planted to corn Zea mays 'Silver Queen'.......... 9

2. Numbers of Belonolaimus longicaudatus as influenced by organic amendments in Arredondo fine sand. . . . . 10

3. Numbers of Hoplolaimus galeatus as influenced by organic amendments in Arredondo fine sand. . . . . . . 12

4. Numbers of Criconemoides ornatum as influenced by organic amendments in Arredondo fine sand. . . . . . . . 14

5. Numbers of rhabditids as influenced by organic amendments in Arredondo fine sand. .......... 15

6. Numbers of diplogasterids as influenced by organic amendments in Arredondo fine sand. . . . . . . . 16

7. Numbers of cephalobids as influenced by organic amendinents in Arredondo fine sand. .......... 18

8. Numbers of dorylaimids as influenced by organic amendinenis in Arredondo fine sand. . . . . . . . . 19

9. Relative numbers of fungi as influenced by organic amendments in Arredondo fine sand. . . . . . . . . 21

10. Relative numbers of bacteria as influenced by organic amendments in Arredondo fine sand. . . . . . . . 22

11. Nitrates in Arredondo fine sand amended with organic materials. .................... 25

12. Average pur cent of germination of Phaseolus vulgaris in ariended soils. ................

13. Average maximum plant heights of Phaseolus vulgaris in the greenhouse experiments. . . . . . . . . 
14. Total green weight of bean pods produced on plants of Phaseolus vulgaris in amended soils... . . . . .

15. Motility of Belonolaimus longicaudatus as influenced by extracts from organic amended Arredondo fine sand. . . 30

Appendix table

1. Numbers of Belonolaimus longicaudatus as influenced by alfalfa meal amendments in Arredondo fine sand . . . 35

2. Numbers of Hoplolainus galeatus as influenced by alfalfa meal amendments in Arredondo fine sand. . . . 35

3. Numbers of Criconemoides ornatum as influenced by alfalfa meal amendments in Arredondo fine sand. . . . 36

4. Numbers of other nematodes as influenced by alfalfa meal amendments in Arredondo fine sand. . . . . . . 36

5. Numbers of aphelenchoid nematodes as influenced by organic amendments in Arredondo fine sand. . . . . . 37

6. Reaction of Arredondo fine sand amended with organic

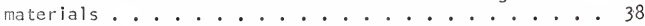

7. Ammonium acetate $(\mathrm{pH} 4.8)$ extractable Ca in Arredondo fine sand amended with organic materials. . . . . . 39

8. Ammonium acetate $(\mathrm{pH} \mathrm{4.8)}$ extractable $\mathrm{Mg}$ in Arredondo fine sand amended with organic materials....... . 40

9. Ammonium acctate $(\mathrm{pH} 4.8)$ extractable $\mathrm{K}$ in Arredondo fine sand amended with organic materials. . . . . . 41

10. Arnmonium acetate $(\mathrm{pH} 4.8)$ extractable $\mathrm{P}$ in Arredondo fine sand anended with organic materials. . . . . . . 42

11. Numbers of Criconemoides ornatum, Hoplolaimus galeatus, and rhabditid nematodes as influenced by alfalfa meal in Arredondo fine sand (laboratery study) . . . . . . 43

12. Relative numbers of bacteria and relative numbers of fungi as influenced by alfalfa meal in Arredondo fine sand (laboratory study)............... 44 


\section{LIST OF FIGURES}

Figure

Page

1. Total $\mathrm{CO}_{2}-\mathrm{C}$ production in Arredondo fine sand amended with different rates of alfalfa meal. . . . . 23 
Changes occur in the chemical, physical, and biological properties of soils into which organic materials have been incorporated (I). One biological change is that certain populations of plant pathogens tend to increase in numbers. The fungus that causes black root rot of tobacco increased greatly on resistant plants when the plants were first treated with aqueous extracts of decomposing green material from rye and timothy (27). This conditioning of the tobacco plants was attributed to toxic substances liberated or synthesized or both during the decomposition of organic material $(26,29)$.

Arother biological change that occurs when organic materials are incorporated into the soil is that populations of certain other plant pathogens tend to decrease in numbers $(25,37)$. Linford et al. (19) reported reduction of a population of a root-knot nematode, Meloidogyne sp., during decomposition of chopped pineapple, sugarcane, and a coarse grass. They attributed this reduction to the build-up of predacious fungi. The occurrences, mechenisms, ard roles in control of nenatodes by predacious or parasitic fungi have been investigated and discussed by numarous auchors $(5,6,7,8,9,13,20,21,22,32)$.

Some workers reported a build-up of predacious nematodes in amonded soils and suggested that these urganisms wore important in the control of piant parasicic nematodes $(19,23)$. Predacious nematodes occur in the families Mononchidae, Tripylidae, Diplogas- 
teridae and Aphelenchidae, and the superfamiles Dorylaimoidea and Mermithoidea (13). The rearing and inoculating of predacious nematodes into soil infested with plant parasitic nematodes was proposed and initial experiments using Mononchus papillatus Bastian carried out by Cobb (4) and Steiner and Heinly (34). Only under laboratory conditions did they demonstrate the effectiveness of M. papillatus in controlling root-knot nematodes.

Other workers believe that organic materials added to the soil may be toxic to plant parasitic nematodes. Ellenby $(10,11)$ found that extracts of certain members of the plant family Cruciferas and mustard oil (allyl isothiocyanate) were toxic to Heterode a rostochiensis Wollenweber. Renninger et al. (30) reporind that hydrogenated fish oil, when sprayed over infested soil, reduced numbers of Radopholus similis (Cobb) Thorne. They hypothesized that control was due to an interference of the respiration and oxidation processes in the nematodes, thus suffocating them. Other organic materials that have been reported to reduce populaticns of plant parasitic nematodes include alfalfa hay, oat straw, lespedeza hay, flax (16), caster pomace (18), sawdust (33), raspberry canes and roots (36), and soybean meal and oil (38).

Blodegradation of organic materials and/or biosynthesis of degraded products result in nematicidal compounds that are active in soils $(17,23,31)$. Sayre et al. (31) obtained and identified a nematicidal compound, butyric acid, from decomposing rye and timothy piant residues. They also suggested that oiher low molecular weight carboxylic acids, such as formic, acetic, and propionic, 
might also be produced during decomposition and be nematicidal. Taylor and Murant (36) found that the polyphenols hydroquinone, catechol, and resorcinol are nematicidal. They suggested that these polyphenols might come from the tannin fraction of decomposing plant materials.

Another theory is that the organic materials in the soil may so alter the chemical equilibrium in the soil that numbers of plant parasitic nematodes are reduced. Johnson (15) reported that, in amended soils, numbers of a root-knot nematode species were reduced at temperatures from 50 to $30^{\circ} \mathrm{C}$ in soils of low and medium moisture levels and at $\mathrm{pH}$ between 4.6 and 5.5. Mankau (24) suggested that control of nematodes in amended soils was due to factors such as alteration in available soil oxygen and nitrogen, and in the pH. Stolzy et al. (35) found that nematodes could survive at a level of $2 \%$ oxygen. Eno et al. (12) observed nematode reduction in soils containing $136 \mathrm{ppm}$ of ammoniacal nitrogen; the largest reduction occurred in soil coitaining 365 ppm of ammoniacal nitrogen. Wallace (39) reported an optimum level of $10 \%$ carbon dioxide for nematodes.

The reduction of numbers of plant parasitic nematodes by the addition of organic amendments to the soil is well documented in the literature. The purpose of this research was to investigate quantitatively some of the factors that might be responsible for this reduction. Factors studied were populations of nematodes, relative numbers of fungi and bacteria, levels of nitrogen and carbon dioxide, ammenium acetate extractable $\mathrm{Ca}, \mathrm{K}, \mathrm{Mg}$, and $\mathrm{P}$, and nematicidal chemicals prodiced by the biodegradation of the organic amendments. 
MATERIALS AND METHODS

Predacious nematode experiment. - Thirty clay pots of a $10-\mathrm{cm}$ size were filled with Arredondo fine sand and autoclaved for forty minutes at 18 psi. After three days, the pots were planted to sweet corn, Zea mays L., 'Silver Queen'. Ten pots were inoculated with fifty hand-picked specimens of the sting nematode, Belonolaimus longicaudatus Rau; ten pots were inoculated with fifty hand-picked specimens of $B$. longicaudatus plus fifty hand-picked specimens of Mononchoides sp. (undescribed); and ten pots were not inoculated with nematodes. All pots were kept in a growth room held at a temperature of $22^{\circ} \mathrm{C}$ with a photoperiod of twe ive hours. Each pot of soil was watered as needed. Plant heights $(\mathrm{cm})$ and green weights (g) of shoots and roots were recorded after eight weeks. Dry weights of shoots and roots were determined after drying at $600 \mathrm{C}$ for fortyeight hours. The soil in each pot was mixed thoroughly and a 100-ml sample was processed by the sugar flotation-centrifugation method (3) ard numbers of $\underline{B}$. longicaudatus and Mononchoides sp. determined for cach pot of soil.

Soil emendinent cxperiments. - An Arredondo fine sand was selected which was infested with the plant parasitic nematodes $B$. longicaudatus, Homlolaimus galeatus (Cobb) Thorne, and Criconemoides ornatus Raski. Rhabditid, diplogasterid, cephalohid, and doryiamid trpes of rematodus were also piesent. Amendments added 
were alfalfa meal, cottonseed meal, or rice straw at rates equivalent to 0,9 , and 18 H.T./ha $(0,4$, and 8 short tons per acre). For each replicate the appropriate anount of the amendment $(0,80$, or $160 \mathrm{~g}), 10 \mathrm{~g}$ of $\mathrm{CaCO}_{3}, 3 \mathrm{~g}$ of fertilizer (10-10-10), and $20 \mathrm{~kg}$ of soil were placed in a concrete mixer and the mixer operated for two minutes. The mixture then was placed in redwood flats $(43 \times$ $25 \times 17 \mathrm{~cm})$. Each treatment was replicated six times, but only five were sampled; the sixth flat was used to replace soil removed from the test flats when sampling. Ten seeds of common bean, Phaseolus vulgaris L., 'Contender' were planted in each flat. The seeds in the flats amended with cottonseed meal germinated poorly or not at all, and these flats were replanted seven weeks after the initiation of the experiment. Three completely randonized experiments were conducted; alfalfa meal was used in each of the three experiments and cottonseed meal and rice straw were used in only one of the experiments.

The following data were recorded weekly: numbers of plant parasitic and other nematodes; relative numbers of fung $i$ and bacteria obtained by plate counts made on rose-bengal and soil-extract agar, respectively (2); soil $\mathrm{pH}$; nitrates by the phenoldisulfonic acid method; and ammonium acetate extractable $\mathrm{Ca}, \mathrm{K}, \mathrm{Mg}$, and $\mathrm{P}(14)$. In addition bean seed gemination, plant heights, and green weights of bean pods were recorded. Laboratory experiments were conducted with the anended soils to obtain data on carbon dioxide-carbon evolution by using $\mathrm{NaOH}$ in a closed system as the absorber of evolved carbon dioxide. Data were statistically analyzed using an analysis of 
variance with 'F' test.

Extraction experiment. - Nine two-quart plastic freezer bags were filled with $300 \mathrm{~g}$ of Arrendondo fine sand. Alfalfa or cottonseed meal at rates equivalent to $18 \mathrm{M} . \mathrm{T} . / \mathrm{ha}(2.4 \mathrm{~g})$ were added to each of three bags and mixed thoroughly. Nothing was added to the other three bags. All nine bags were placed in an incubator at $25^{\circ}$ $C$ and water added to each when needed to keep the soil moist. Also, the soil was stirred to keep it aerated. After seven, fourteen, and twenty-one days, three hags, one each containing alfalfa meal and cottonseed meal and one control, were removed from the incubator and each placed in a 1,000-ml beaker with $300 \mathrm{ml}$ of a weak aqueous solution of $\mathrm{NaOH}$ at $\mathrm{pH} 11$ and mixed for 1.5 hours with a cone-diven stirrer. The solution was readjusted to $\mathrm{pH} 11$ with $0.5 \mathrm{~N} \mathrm{NaOll}$ and mixed another 1.5 hours. The supernatant was centrifuged for fifteen minutes at $2,500 \mathrm{rpm}$, then filtered through Whatman's \#1 filter paper in a Buchner funnel. The solution then was acidified slowly to a $\mathrm{pH} 4.5$ with $0.5 \mathrm{~N} \mathrm{HCl}$, placed in a separatory funnel and $200 \mathrm{ml}$ of anhydrous ether added. The solution was shaken vigorously and allowed to separate, with both fractions being collected. The water fraction was again washed with $200 \mathrm{ml}$ of ether. The two ether fractions were combined and the ether was evaporated under a partial vacuurn. The residue was taken-up in $5 \mathrm{ml}$ of water and this was used in the bioassays.

The bioassays were conducted with active specimens of $\underline{B}$. longicaudatus. Ten specimens were placed in a BP: watch glass containing 
$1 \mathrm{ml}$ of the extracts from either the alfalfa meal, cottonseed neal, unamended control, or distilled water. Each of the four treatments was replicated three times. Motility data were taken at the beginning and end of each test which varied from twenty-four to thirty hours in duration. Motility was determined by applying tactile stimulation with a dental pulp canal file while observing the specimen with a dissecting microscope. 


\section{RESULTS}

Predacious nematode experiment. - An average of 140 specimens of Belonolaimus longicaudatus per pot were recovered from those pots inoculated with fifty specimens of this species only. An average of 207 specimens of $B$. longicoudatus and seventy-four specimens of Mononchoides sp. Were recovered from pots inoculated with fifty specimens of each organism (Table 1). However, populations of each nematode varied greatly between individual pots in both treatments.

Average dry weights of the shoots of corn plants were highest in the control and lowest where $\underline{B}$. longicaudatus was used alone (Table 1). Average dry weights of the roots were highest where both nematodes were used together and lowest where $\underline{B}$. Iongicaudatus was used alone. Huch variation was noted between dry weights of corn plants in individual treatments.

$$
\text { Soil amendment experiments. - Population levels of B. longi- }
$$
caudatus were reduced by the 9 and $18 \mathrm{M}$.T./ ha rates of the amend-

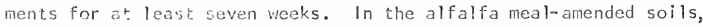
populations of $\underline{B}$. iongicaudatus in the controls were noted to increase during the fourth veek and to reach raximum numbers during the seventh week (Tab!e 2). Populations in the 9 M.T./ha treatment started to increase during the seventh week and obtained a maximum number by the eleventh week. Fopulations in the $18 \mathrm{M}$. T./ha treatment started to increase in the eleventh week. Bean plants were producing fruit by the seventh weok and continued to do so through the twelf th week when the experinent was stopped. 
Table 1. Average plant heights and weights and recovery of Belonolaimus longicaudatus and Mononchoides sp. nematodes eight weeks after inoculation into soil planted to corn Zea mays 'Silver Queen'.

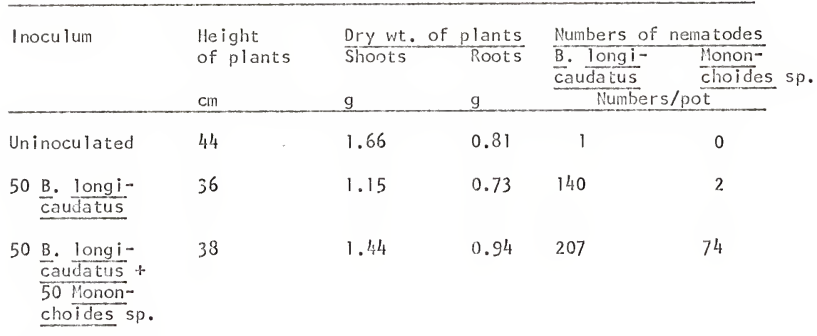




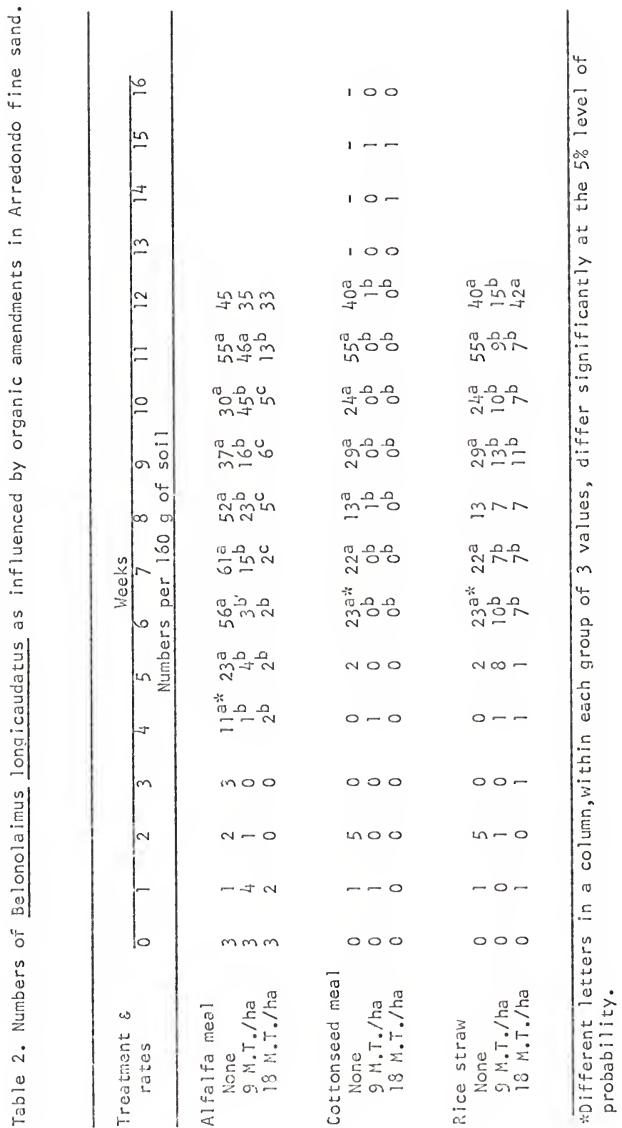


In the cottonseed meal-amended soil, populations of the sting nematode were almost undetectable throughout the experiment at both the 9 and $18 \mathrm{M} . \mathrm{T} . /$ ha rates (Table 2). Populations in the control were significantly higher than in the treatments from the sixth week through the twelfth week. As stated above, the seeds planted at the initiation of the test failed to germinate and the flats were reseeded after seven weeks. These seeds germinated considerably better (Table 12) and plant growth was good (Tables 13 and 14), yet suppression of the sting nematode populations was evident through the sixteenth week.

In the rice straw-amended soils, sting nematode populations began to increase in the twelfth week (Table 2). The number of nematodes in the control was significantly higher than the numbers in the 9 and 18 M.T./ha treatments from the sixth through the eleventh weeks. By the twelfth week the population of nematodes had increased greatly in the $18 \mathrm{M} . \mathrm{T}$. /ha rate while the population in the $9 \mathrm{M} . \mathrm{T} . /$ ha rate remained at a low level. There were mature plants in all flats by the seventh week of the experiment.

Populations of Hoplolaimus galeatus declined in all treatments (Table 3). In the alfalfa meal treatments, numbers were significantly less than in the controls in the second and third weeks. In the cottonseed meal treatments, numbers were significantly less than in the controls from the third through the twelfth week. In the rice straw treaiments, numbers were signiricantly less than in the controls only from the second through the fourth week. 


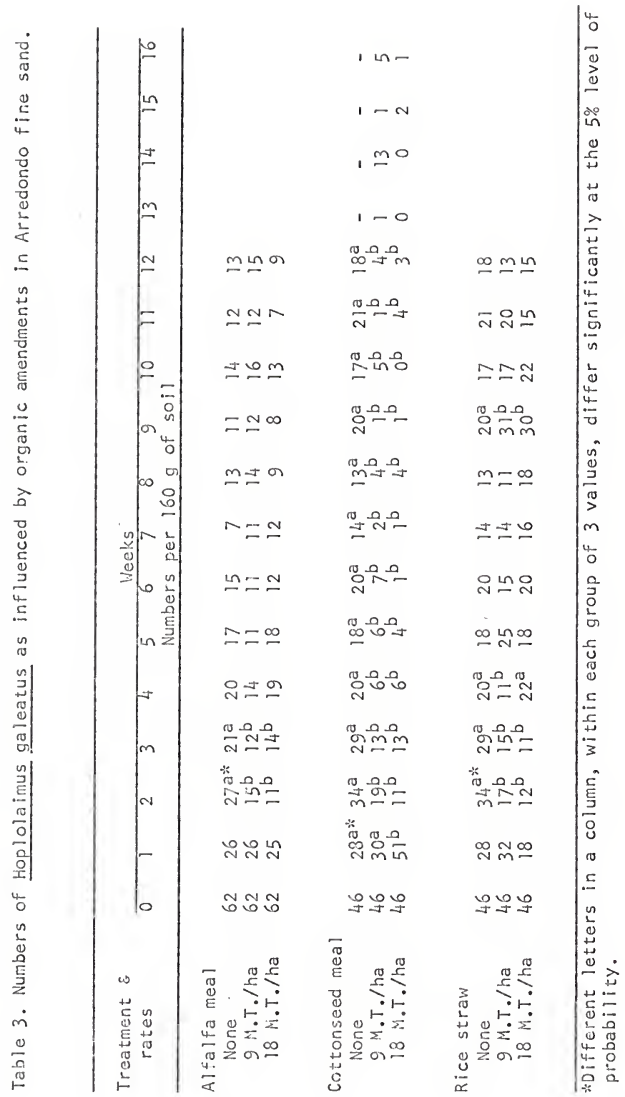


(Table 4). Numbers in the controls initially declined at a slower rate than in the amended soils but no continuous significant differences occurred.

Number of rhabditid nematodes in soil amended with alfalfa meal increased significantly over the controls after the first week (Table 5). In the 9 M.T./ha rate, numbers reached a peak in the third week and declined sharply in the fourth week. In the I8 M.T./ha rate, numbers reached a peak in the second week and declined sharply in the fifth week but remained significantly higher than the control through the seventh week. Rhabiditids in the cotton seed meal treatment reached maximum population levels in the second week. In the 9 M.T./ha rate, numbers declined by the sixth week to levels insignificant from the control. The 13 M.T./ha rate remained significantly different from the control through the eleventh week. Rhabditids in the rice straw treatments reached maximum population levels in the third and fourth weeks. However, these maximum levels were far below those of the other treatments. In both the 9 and $18 \mathrm{M} . \mathrm{T}$./ha rate treatments, numbers declinod sharply the week after maximum numbers were reached,

The diplogasterid nematodes in the alfalfa meal-amended soils increased significantly to maximum population levels in the second week, then decreased rapidly thereafter (Table 6). Populations in the cottonseed meal-amended soil increased significantly in the first week and by the second week decreased to almost undetectable levels. Populations of diplogasterids in the soils amended with rice straw were almost undetectable aiter the pretreatment counts. 


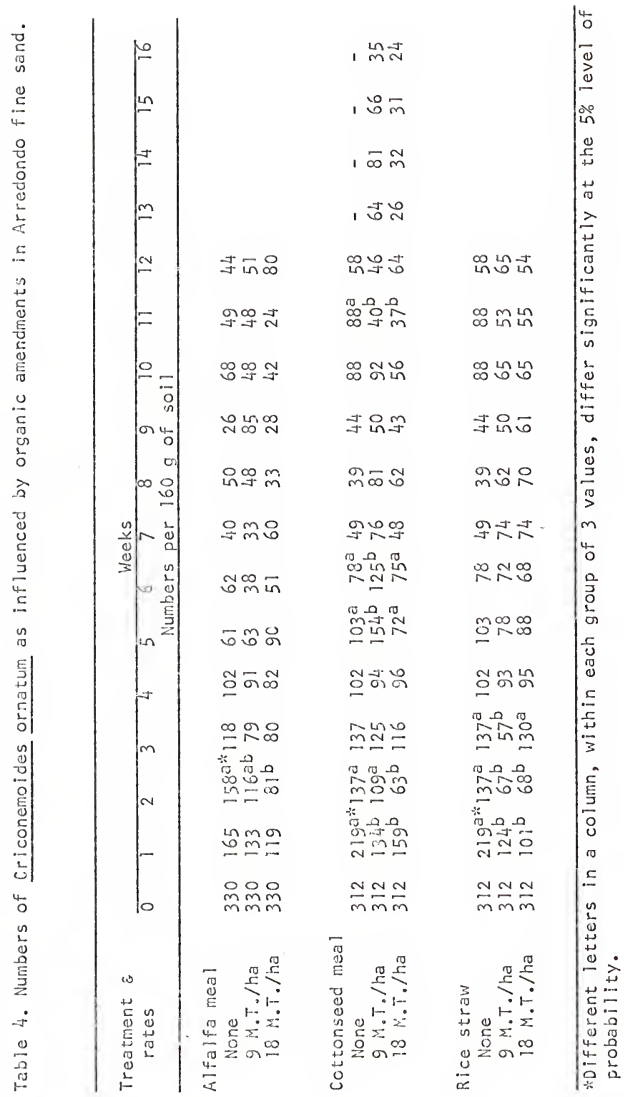


$-15-$

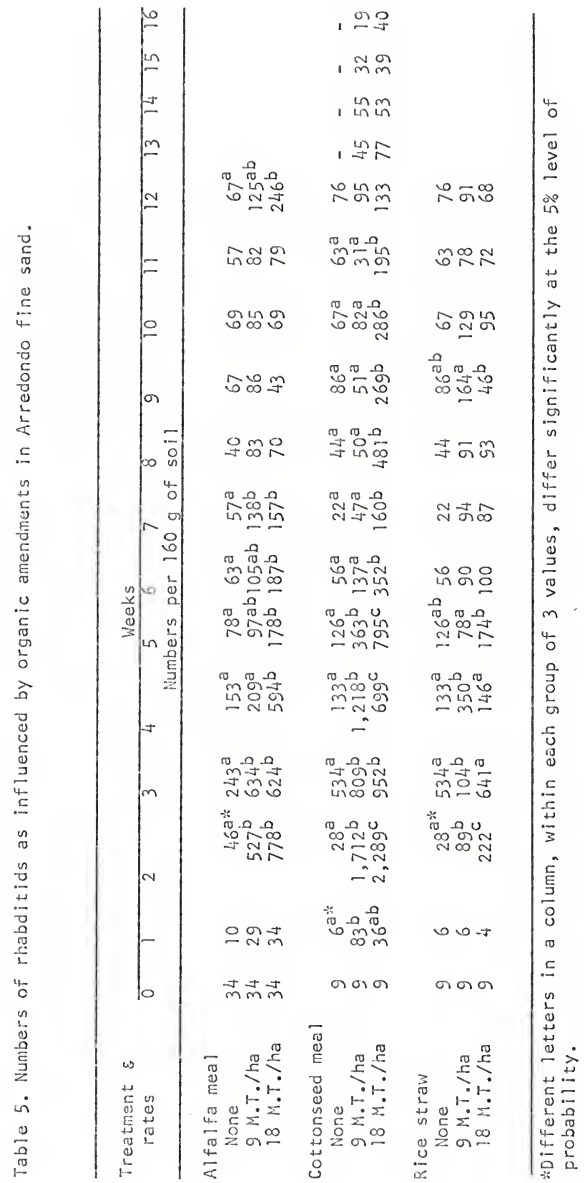




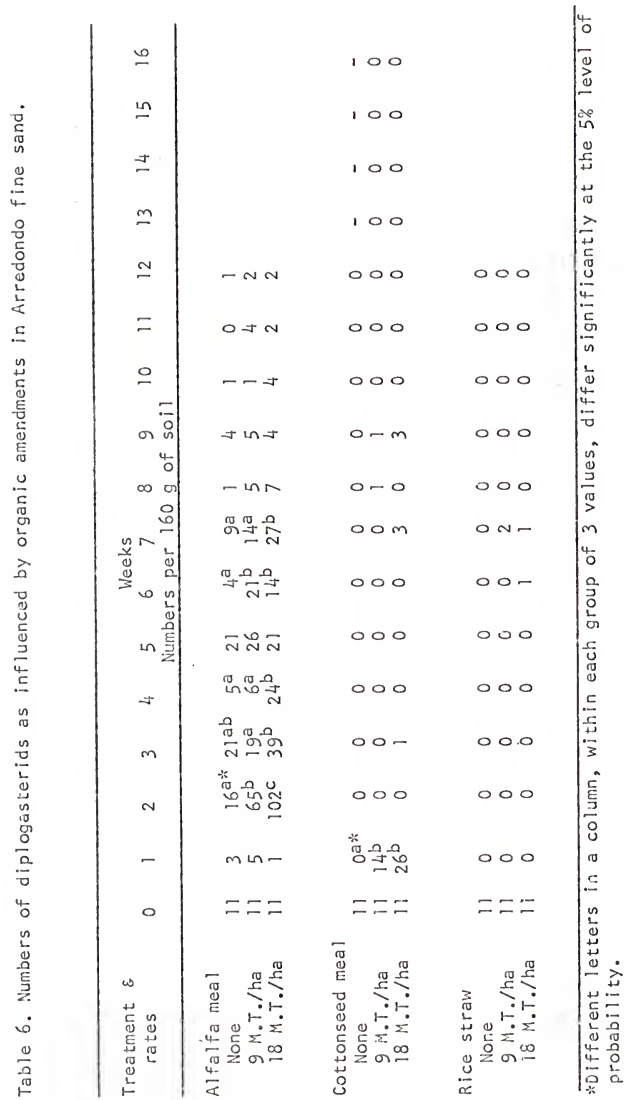


The numbers of cephalobid nematodes in the alfalfa meal amended soils were not significantly different from the control until the seventh week at which time they were lower in number (Table 7). By the eighth week, numbers in the amended soils were higher than in the control and this trend held generally during the remainder of the experiment, although the differences were not always significant. Populations in the cottonseed meal-amended soil remained very low through the first.fourteen weeks, then increased sharply in the fifteenth week. Populations of cephalobids in the rice straw-amended soils were low through the first ten weeks, with a signifirant increase occurring in the eleventh week in the $9 \mathrm{M} . \mathrm{T} . /$ ha rate.

The dorylaimid nematodes in the alfalfa meal-amended soils decreased and remained at very low numbers throughout the experiment. Those in the control increased in the sixth week and, with the exception of the eighth week, remained significantly higher than in the treatments through the twelfth week (Table 8). Populations in the coitonseed meal-amended soils behaved very similar to those in alfalfa amended soils. Dorylaimids in the rice straw-amended soils decreased in the first week and remained at low insignificant leveis throughout the remainder of the experiment except for the ninth and eleventh weeks. Very low and erratically occurring populations of aphelenchoid nematodes were present (Appendix Table 5).

The relative numbers of fungi were significantly higher in the alfalfa meal-amended soils than in the control throughout the experi- 


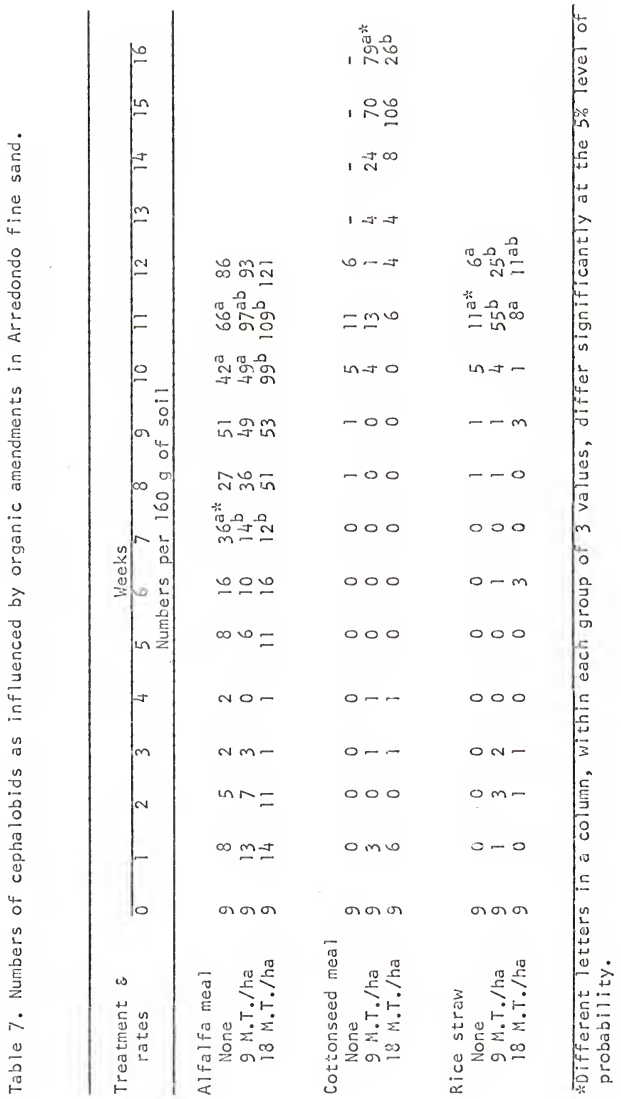




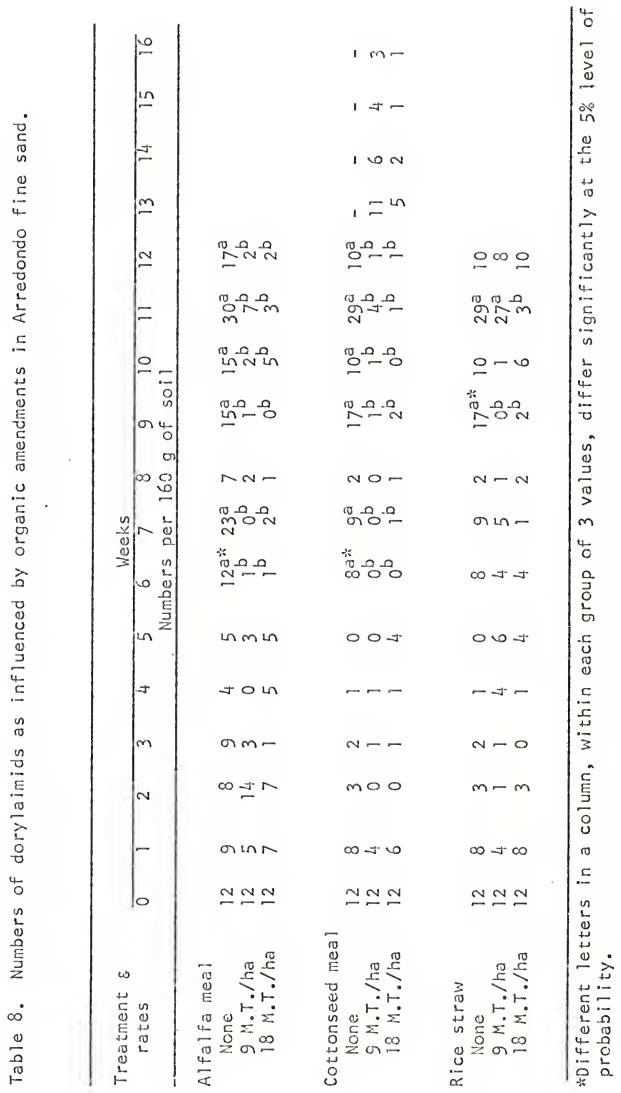


ment, except for the tenth week (Table 9). Reiative numbers in the cottonseed meal-amended soils were significantly different than in the control the first week and from the fourth week to the eleventh week. In the 9 M.T./ha rate, relative numbers were higher than in the control, but in the $18 \mathrm{M}$.T./ha rate relative numbers were lower in several cases than in the control (Table 9). Relative numbers of fungi in the 9 and $18 \mathrm{M} . \mathrm{T}$./ ha rates of rice straw were significantly higher than the control from the third week through the eighth week. Relative numbers in the $18 \mathrm{M} . \mathrm{T} . /$ ha rate were also significantly higher in the tenth and eleventh weeks but not in the ninth week.

The relative numbers of bacteria were significantly higher in alfalfa meal-amended soils at the $18 \mathrm{M} . \mathrm{T}$./ha rate than in the controls throughout the experiments except in the ninth week (Table 10). In the 9 M.T./ha rate, relative numbers usually were not significantly different from the controls. The relative numbers in the cottonseed meal-amended soils were significantly higher than in the controls throughout the experiments except in the second, third, and eleventh weeks at the 9 M.T./ha rate, and the third week at the 18 M.T./ha rate. The relative numbers of bacteria in soil amended with rice straw were significantiy higher than in the control from the third to the fifth week at the 18 M.T./ha rate and in the fifth week at the 9 M.T./ha rate.

Total carbon dioxide evolution in soil amended with alfalfa meal was significanily different from the controls (Fig. 1). The highest production was in the $18 \mathrm{H.T}$./ ha rate with a total production of $235 \mathrm{mg}$ per $100 \mathrm{~g}$ of soil in 37 days as compared to $17 \mathrm{mg}$ in the 


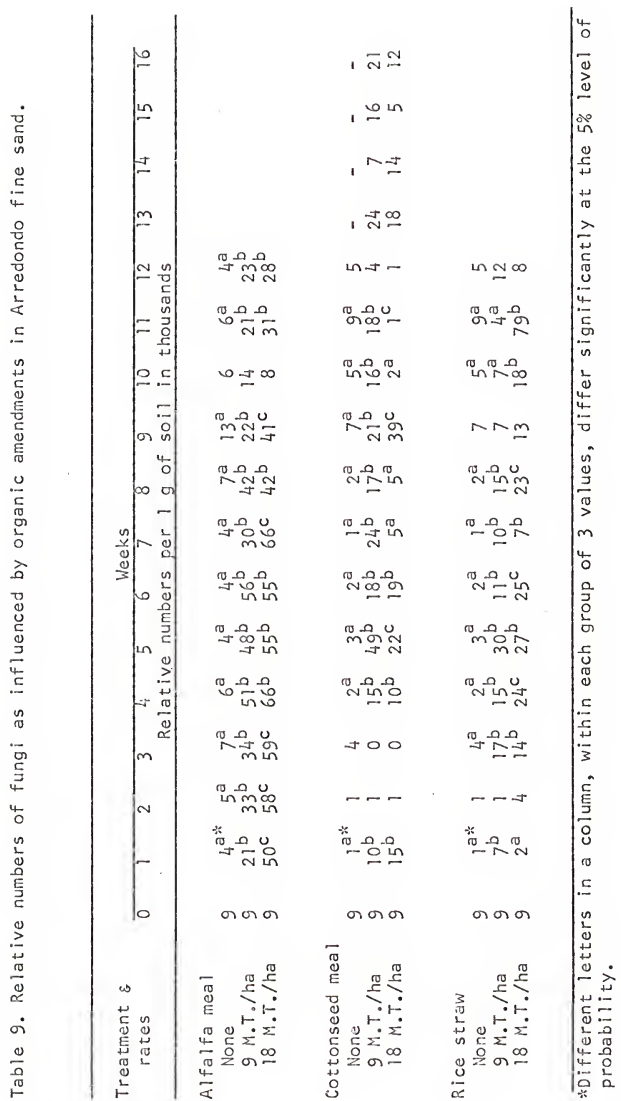




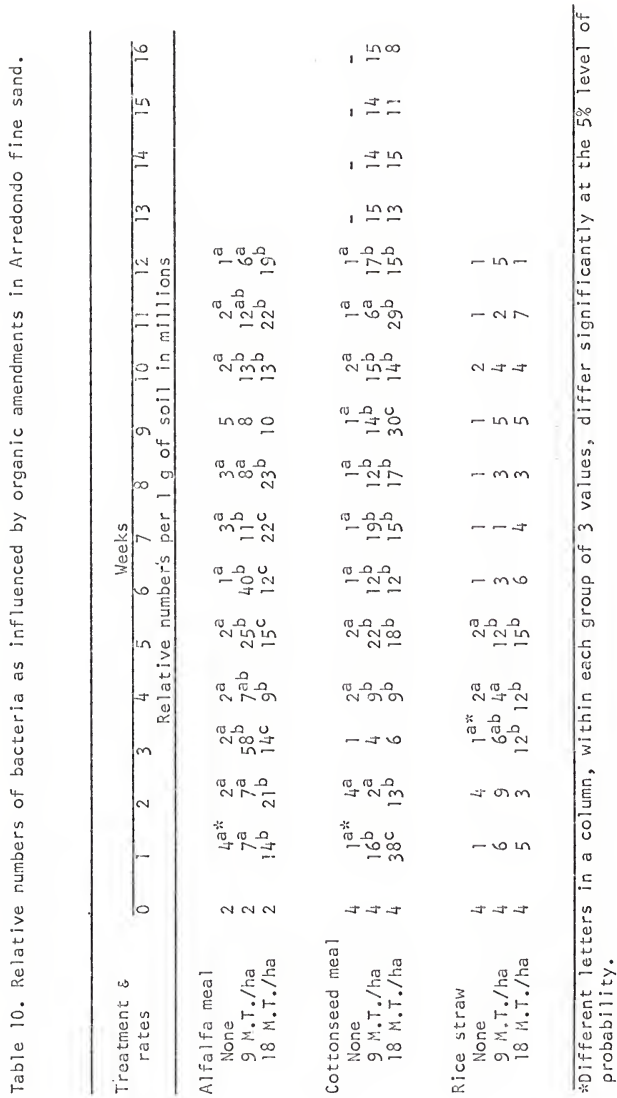




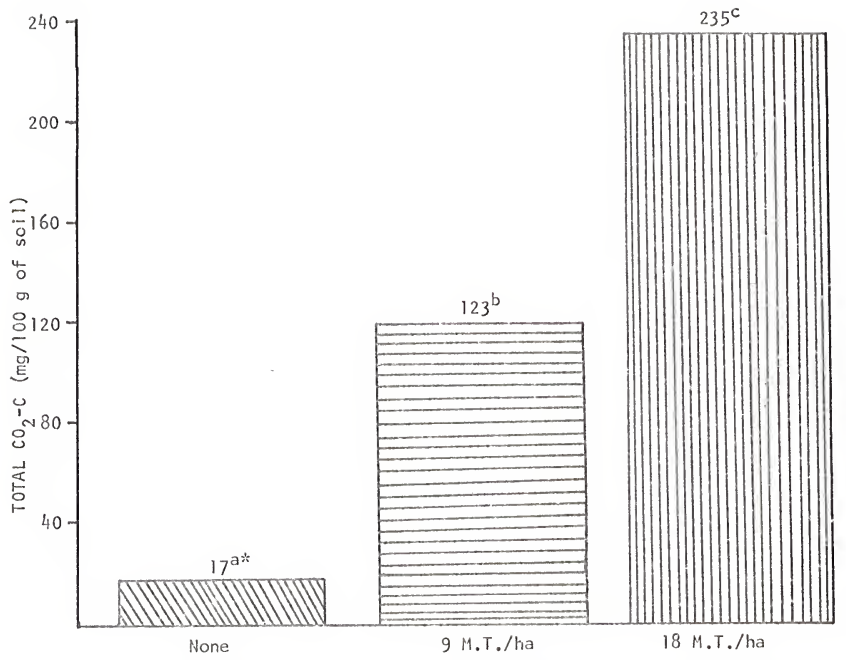

Figure 1. Total $\mathrm{CO}_{2}-\mathrm{C}$ production in Arredondo fine sand amended with different rates of alfalfa meal.

:Different letters means significance at the $5 \%$ level of probability. 
control. Production was intermediate at the 9 M.T./ha rate.

Nitrate accumulation in the $18 \mathrm{M} . \mathrm{T} . /$ ha rate of alfalfa meal remained significantly higher than the control from the third through the twelfth week and in the 9 M.T./ha rate from the third through the fifth week (Table 11). The highest nitrate accumulation was recorded in the $13 \mathrm{M} . \mathrm{T}$./ ha rate of alfalfa meal with a high of 43 ppm in the fifth week as compared with a high of $6 \mathrm{ppm}$ in the fourth week in the control. Accumulation was intermediate in the 9 M.T./ha rate at $29 \mathrm{ppm}$ in the fourth week. Nitrate accumulation in soil amended with cottonseed meal at 18 M.T./ha was significantly higher than in the controls from the fifth through the twelfth week with the exception of the tenth week. In the 9 M.T./ha rate, accumulation was significantly higher than in the control in the third week and from the fifth through the twelfth weeks. Levels of nitrates were very low in the rice straw-amended soils. Such a wide $C: N$ ratio existed that the nitrogen was immobilized by the third week, thereby causing plants to suffer a nitrogen deficiency. Nitrogen deficiency did not occur in the plants grown in soils amended with alfalfa meal and cottonseed meal.

No consistent differences in pH and amcunts of ammonium acetate extractable $\mathrm{Ca}, \mathrm{K}, \mathrm{Mg}$, and $\mathrm{P}$ were observed between treatments in the experiments (Appendix Tables 6,7,8,9, and 10).

Germination of seed of Phaseolus vulgaris was inhibited in soils amended with alfalfa meal and cottonseed meal (Table 12). By the fifth week, all plants in the cottonseed meal-amended soil were dead. The 


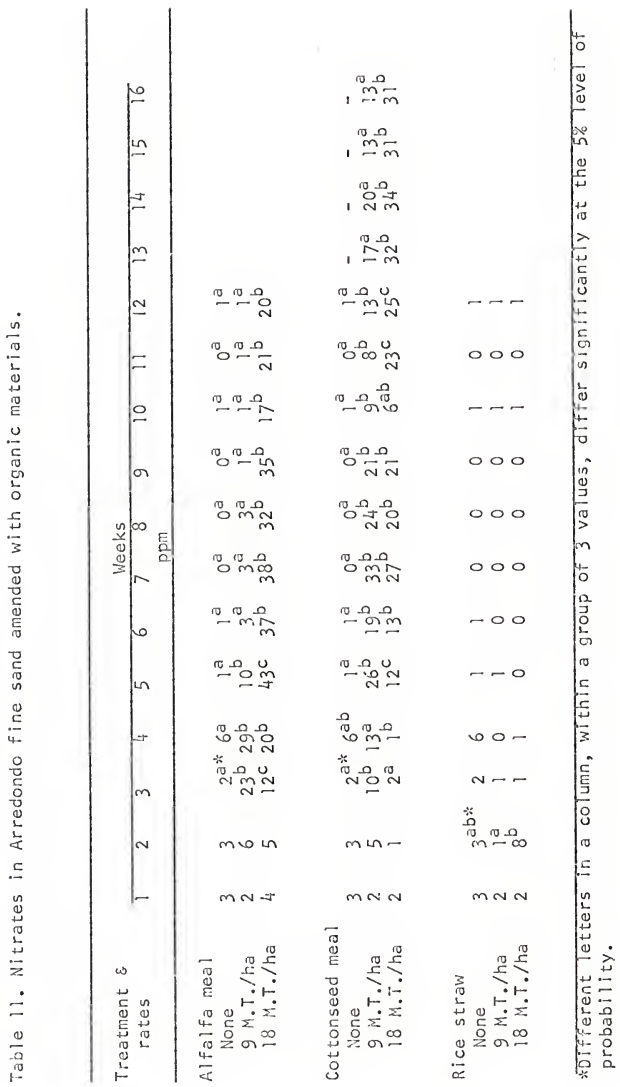


Tabie 12. Average per cent of germination of Phaseolus vulgaris in anended soils.

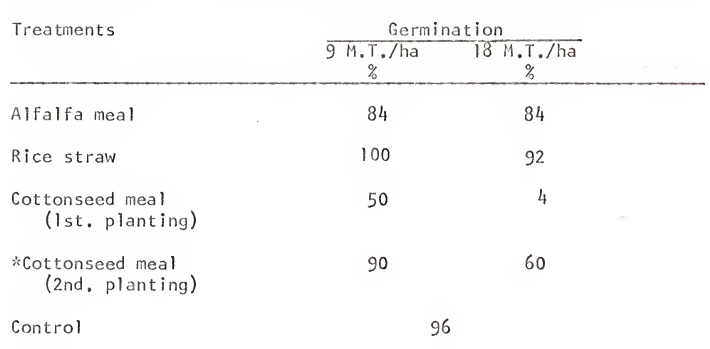

*Replanted in the 7 th week of the experiment after all plants in the soil amended with cottonseed meal at $18 \mathrm{M}$.T./ha died. 
soil was replanted in the seventh week; more seeds germinated and the plants survived.

The greatest average maximum height of bean plants was 43.5 $\mathrm{cm}$ and occurred in the $9 \mathrm{M} . \mathrm{T}$./ ha rate of cottonseed meal three weeks after replanting (Table 13). The least average maximum height was $21.9 \mathrm{~cm}$ and occurred in the $18 \mathrm{M} . T$./ ha rate of cottonseed meal. Inhibition of plant growth was still present in the $18 \mathrm{M} . \mathrm{T}$./ha rate of cottonseed meal eleven weeks after iniciation of the experiment.

The total green weights of bean pods produced by the plants in the $9 \mathrm{M} . T$. Ina rate of aifalfa meal was the highest at $511.6 \mathrm{~g}$ (Table 14). The lowest weights occurred in the rice straw with $50.2 \mathrm{~g}$ and $31.9 \mathrm{~g}$ for the 9 and $18 \mathrm{M} . \mathrm{T}_{\text {. }} /$ ha rates, respectively, with weights produced in cottonseed meal-amended soils intermediate.

Extraction experiment - At the end of seven days of incubation, extracts from both the alfalifa meal and cottonseed meal reduced motility of specimens of $\underline{B}$. longicaudatus to $63 \%$ and $50 \%$, respectively. At the end of fourteen days of incubation, specimens were reduced to $23 \%$ motility in the alfalfa meal and $20 \%$ in the cottonseed meal and at the end of twenty-one days of incubation to $67 \%$ for alfalfa meal and $40 \%$ for cottonseed meal (Table 15). 
Table 13. Average maximum plant heights of Phaseolus vulgaris in the greenhouse experiments.

\begin{tabular}{|c|c|c|}
\hline \multirow[t]{2}{*}{ Treatments } & \multicolumn{2}{|c|}{ Plant heights } \\
\hline & $\begin{array}{c}9 \mathrm{M} . \mathrm{T} . / \mathrm{ha} \\
\mathrm{cm}\end{array}$ & $\begin{array}{c}18 \text { M.T./ha } \\
\mathrm{cm}\end{array}$ \\
\hline Alfalfa meal & 37.5 & 33.8 \\
\hline Rice straw & 31.8 & 30.1 \\
\hline *Cottonseed meal & 43.5 & 21.9 \\
\hline Control & & \\
\hline
\end{tabular}

*The heights recorded in the alfalfa meal, rice straw, and control treatments were taken eleven weeks after planting. The heights recorded in the cottonseed meal treatment were taken three weeks after planting. 
Table 14. Total green weight of bean pods produced on plants of Phaseolus vulgaris in amended soils.

\begin{tabular}{|c|c|c|}
\hline Treatments & $\begin{array}{c}\text { Green } \\
9 \text { M.T./ha } \\
\mathrm{g}\end{array}$ & $\frac{\text { we ight }}{18 \mathrm{M.T.} / \mathrm{ha}}$ \\
\hline Alfalfa meal & 511.6 & 294.3 \\
\hline Rice straw & 50.2 & 31.9 \\
\hline *Cottonseed meal & 306.9 & 126.4 \\
\hline Control & & 329.1 \\
\hline
\end{tabular}

*Growth period of plants in the cottonseed meal treatments were two weeks shorter than the other treatments. 
Table 15. Motility of Belonolainmus longicaudatus as influenced by extracts from organic amended Arredondo fine sand.

$$
\frac{7 \text { days } \quad 14 \text { days } \quad 21 \text { days }}{\text { Per Cent Motility of Specimens }}
$$

$$
\text { Alfalfa meal }
$$

18 M.T./ha

63

50

80

100

Distilled

water

Cottonseed meal

18 M.T./ha

None
23

67

0

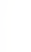

$-87$

20

87

100

97

100 
Predacious nematode experiment. - The results of this experiment indicate that the species of Mononchoides used provides little, if any, biological control of B. longicaudatus. No explanation can be given as to why roots and shoots of corn plants weighed more, and why more B. longicaudatus and Mononchoides sp. occurred when they were used together than where equal numbers of $\underline{B}$. longicaudatus was used alone.

Soil amendment experiments. - A reduction in numbers of plant parasitic nematodes occurred in the amended soils. All amendments at both the 9 and $18 \mathrm{M}$.T. / ha rates reduced population levels of $B$. longicaudatus for at least seven weeks. Phaseolus vulgaris did not appear to be a good host for either $\underline{H}$. galeatus or $\underline{C}$. ornaturn since populations declined in all treatments. However, numbers of specinens of $\underline{H}$. galeatus in the controls declined at a significantly slower rate than in the treatments of the cottonseed meal.

The large and rapid build-up of rhabditid and diplogasterid nematodes is an illustration of populations of nematodes increasing when their food sources increase.

The build-up of cephalobids appeared to be independent of the organic amendments presenting a reverse population trend than the other "saprophagous" nematodes.

The dorylaimid and aphelenchoid nematode populations did not increase in the anended soils. Thus no evidence was obtained to indicate that they were factors in the reduction of population 
levels of the plant parasitic nenatodes.

The relative numbers of fung $i$ and bacteria were significantly higher in the amended soils than in the controls with a few exceptions. Large increases and fluctuations in numbers of zymogenous organisms, which occurred, are to be expected when a biodegradable organic material is added to the soil (1). At no time were predacious or parasitic forms observed in association with the thousands of nematodes counted. Thus no evidence was obtained to indicate that predacious or parasitic fungi or parasitic bacteria were factors in the reduction of population levels of the plant parasitic nematodes.

The carbon dioxide evolution and nitrate accunilation reflects the biociegradability and $C: N$ ratio of the organic amendments. The highest'total of $235 \mathrm{mg}$ of carbon dioxide per $100 \mathrm{~g}$ of soil was probably far below lethal concentrations. Also, the highest nicrate accumulation of $43 \mathrm{ppm}$ is far below the inhibitory level of $136 \mathrm{ppm}$ reported by Eno et al. (12). Therefore, carbon dioxide evolution and nitrate ascumulation apparently were not related to plant parasitic nematode reduction.

The inhibition of seed germination and retardation of seedling growth of $\underline{P}$. vulgaris in cottonseed meal and alfalfa meal-amended soils were similar to those noted by Patrick et al. (29). They attributed this reduction in plant development to phytotoxic properties formed by the decomposition of plant residues.

Extraction experiment. - Crude extracts from both alfalfa meal and cottonseed meal-amended soils reduced motility of specimens of B. longicaudalus. The greatest reduction in motility occurred in 
the second week of incubation. The products responsible for the decrease in motility could be the same or similar to those carboxylic acids characterized by Sayre et al. (31) and/or those polyphenols characterized by Taylor and Murant (36) because the procedures used would have extracted both groups of compounds. The existence of these compounds in the soil could have accounted for the reduction of populations of plant parasitic nematodes observed in the amendment experiments.

None of the factors measured, e. g., fungi, nematodes, etc., could be linked to reduction in numbers of plant parasitic nematodes. Extracts from amended soils did affect Belonolaimus longicaudatus, and $\mathrm{I}$ conclude, therefore, that the products of the decomposing organic amendments were directly nematicidal and these products were, in part, responsible for reduction in numbers of plant parasitic nematodes. 
APPENDIX

Explanation of Tables

Tables $1,2,3$, and 4 contain the nematode data obtained with lower rates of alfalfa meal that were used in the initial amendment experiment.

Table 5 contains the data on numbers of aphelenchoid nematodes in the amendment experiments.

Tables $6,7,8,9$, and 10 contain the pH data and available nutrient data obtained in the amendment experiments.

Tabies 11 and 12 contain the nematode data and relative numbers of bacteria and fungi data that were obtained at the same time the carbon dioxide data were obtained in the laboratory experiments. 


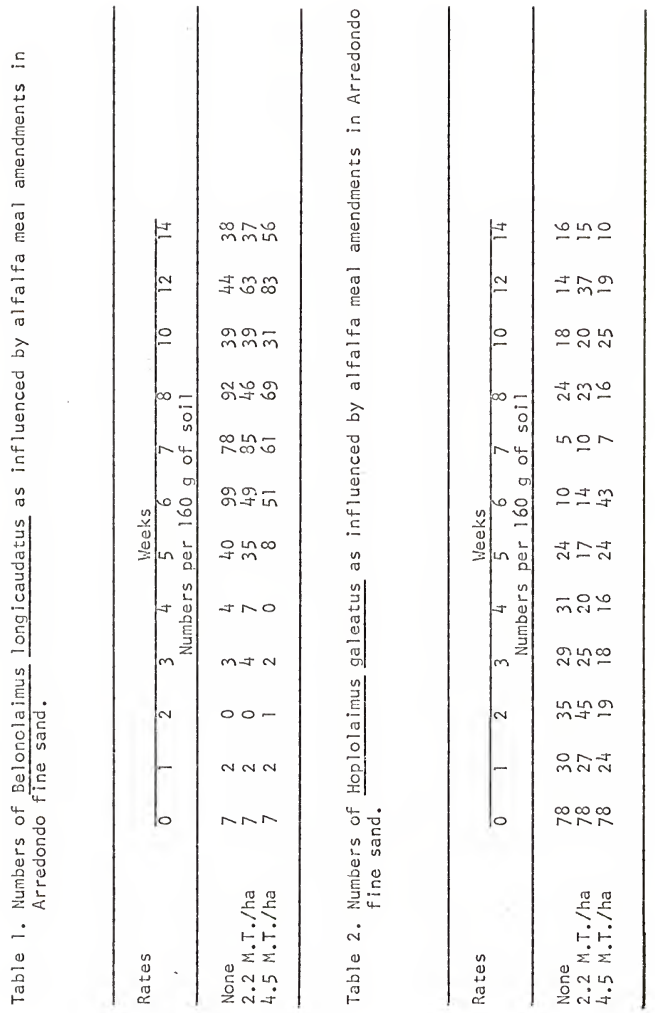




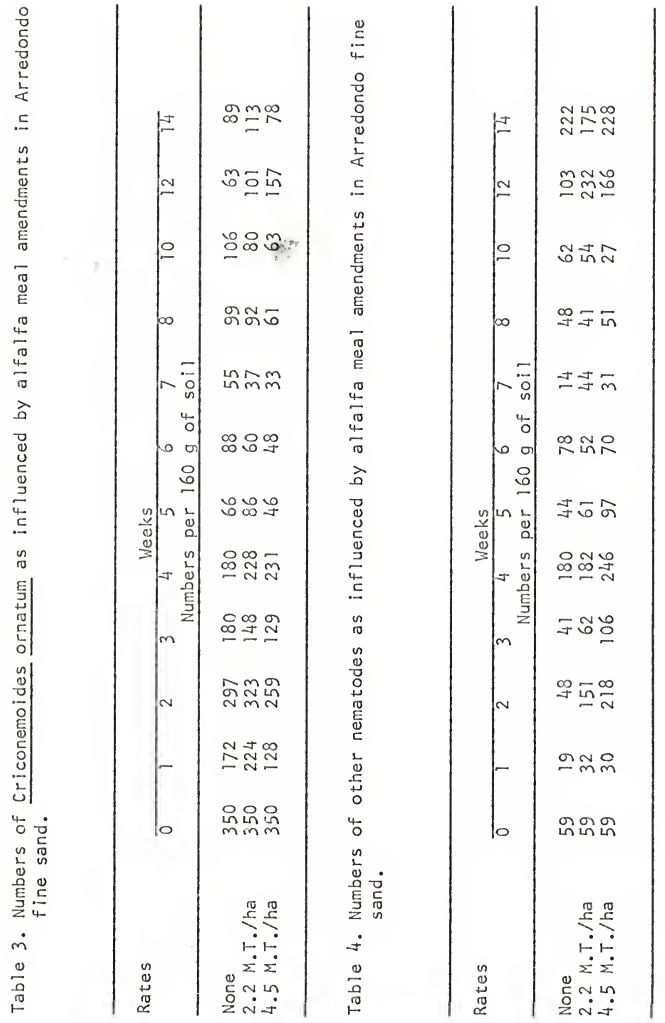




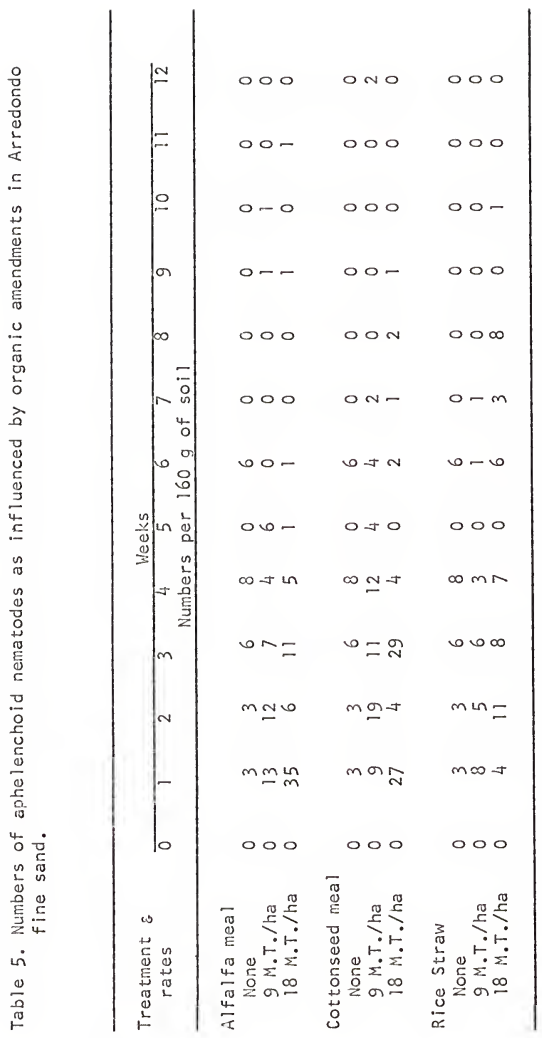




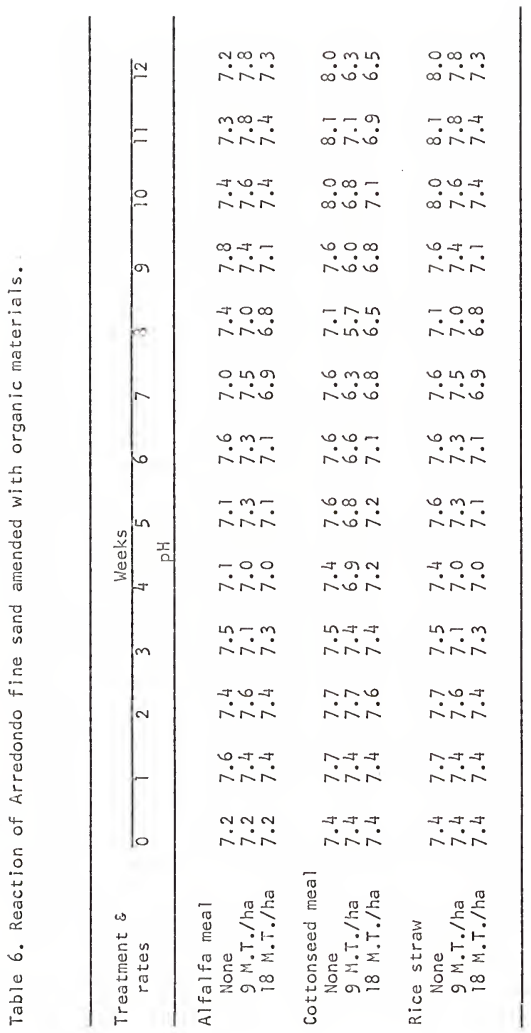




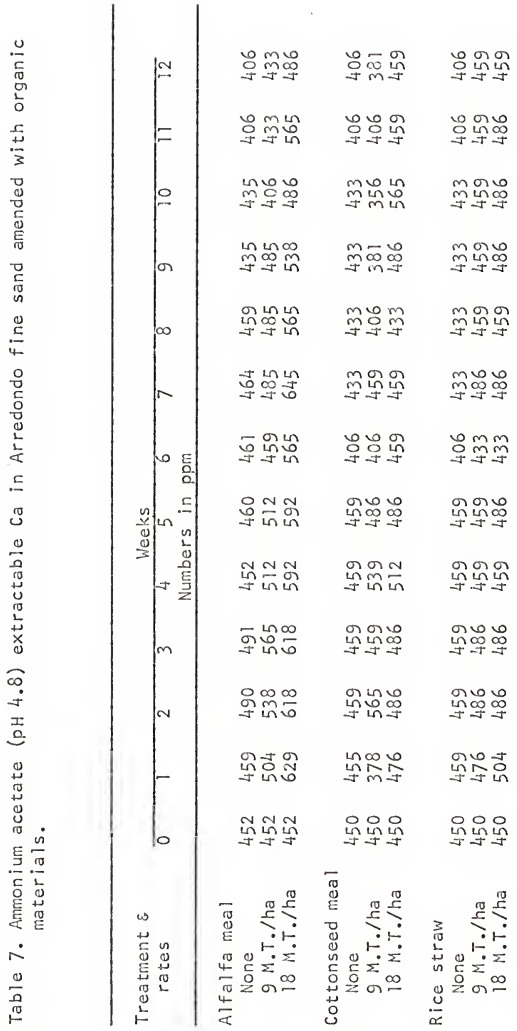




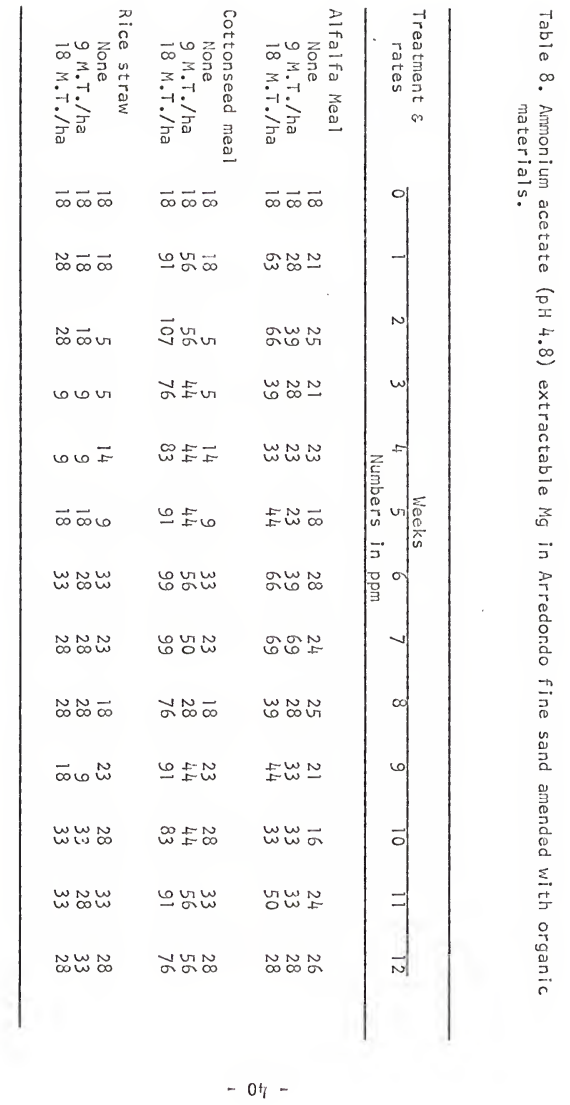




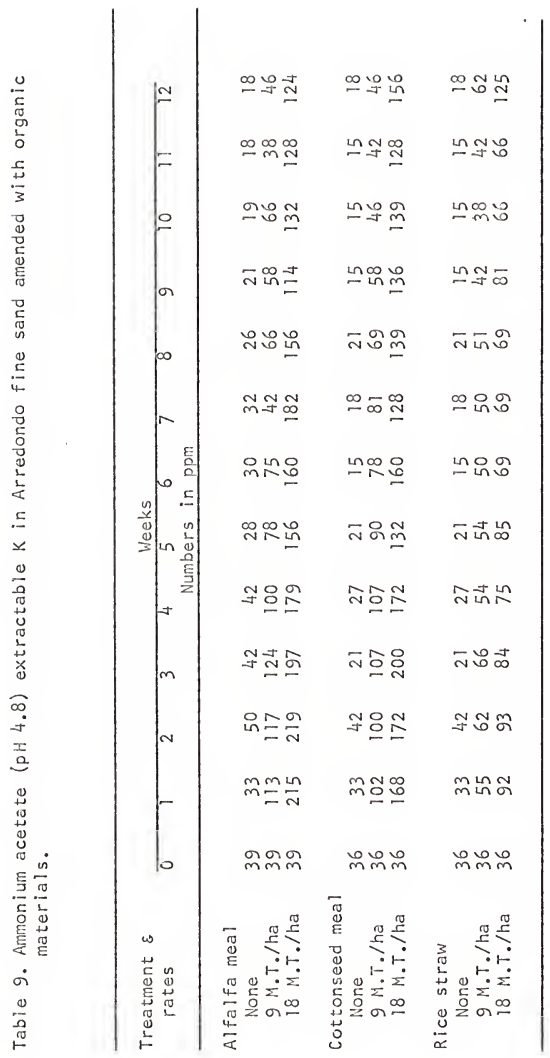




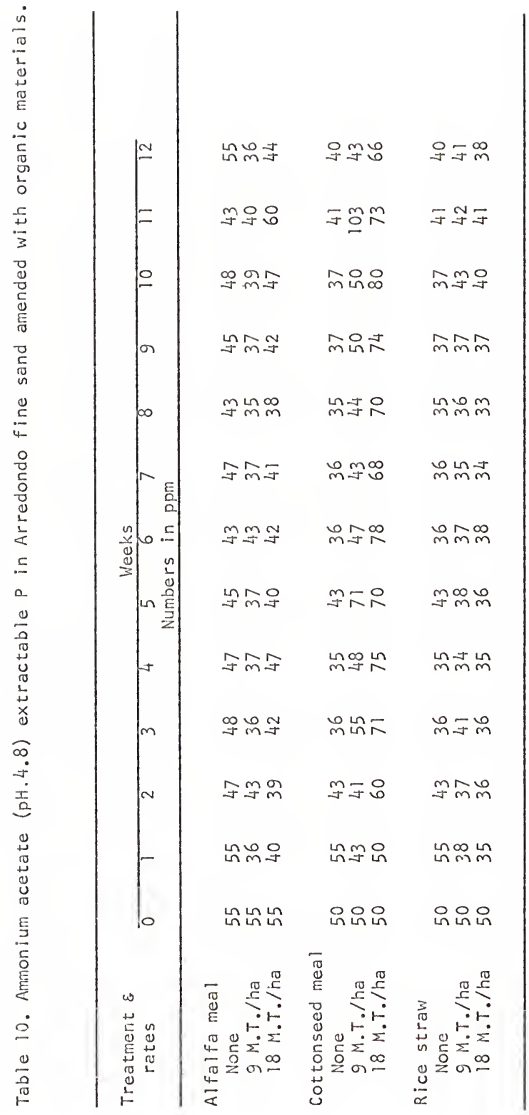




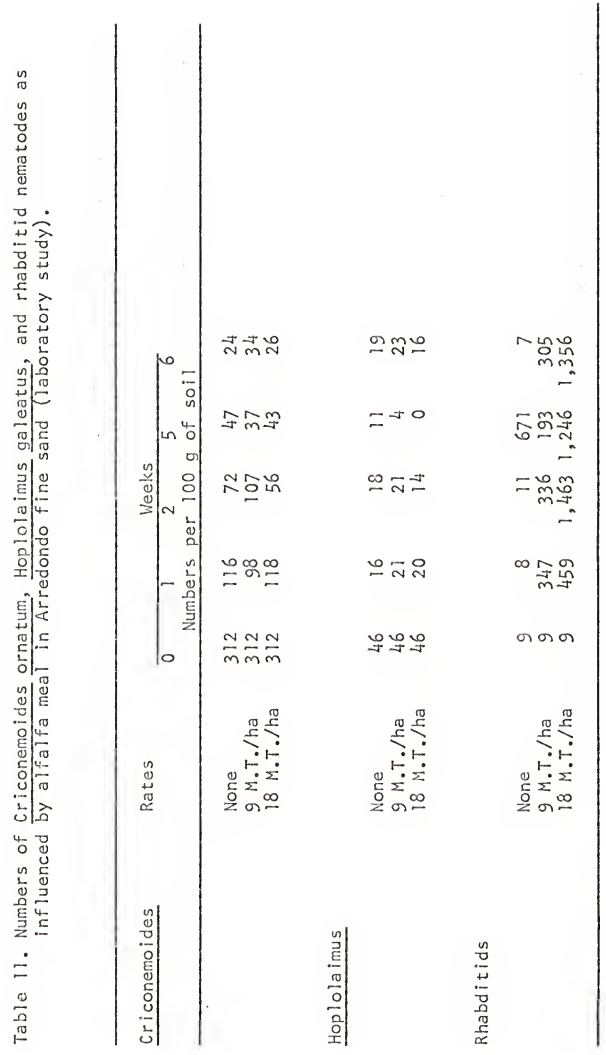




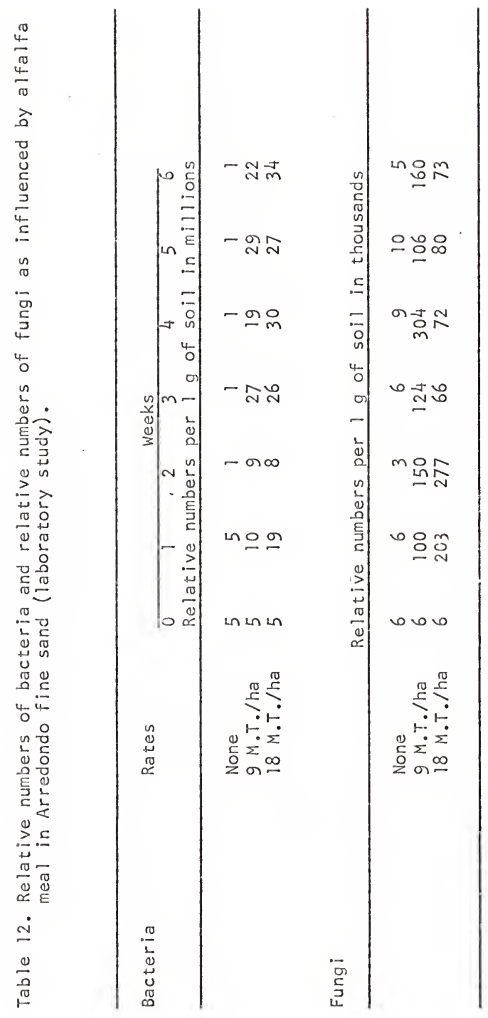




\section{LITERATURE CITED}

1. Alexander, M. 1964. Introduction to soil microbiology. John Wiley and Son, Inc., N. Y. 472.pp.

2. Allen, 0. N. 1957. Experiments in soil bacteriology. Burgess Publishing Co. Minneapolis, Minn. $117 \mathrm{pp}$.

3. Caveness, F. E., and H. J. Jensen. 1955. Modification of the centrifugal flotation technique for the isolation and concentration of nematodes and their eggs from soil and plant tissue. Proc. Helminthol. Soc. Wash. 22:87-89.

4. Cobb, N. A. 1920. Transference of nematodes (Mononchs) from place to place for economic purposes. Science. N. S., 51 $(1330): 640-641$.

5. Cooke, R. C. 1963. The predacious activity of nematode trapping fungi added to soil. Ann. Appl. Biol. 51:295-300.

6. Drechsler, C. 1953. Two new nematode capturing fungi. Phytopathology 53:405(Abstr.).

7. Duddington, C. L. 1955. Inter-relations between soil microflora and soil nematodes 284-301, - In Kevan (ed), Soil zoology. Academic Press Inc., N. Y. 512..pp.

8. Duddington, C. L., and C. M. G. Duthoit. 1960. Green manuring and cereal root eelworm. Plant Pathol. 9:7-9.

9. Duddington, C. L., C. O. R. Everard, and C. M. G. Duthoit. 1961. Effect of green manuring and a predacious fungus on cereal root eelworm in oats. Plant Pathol. 10(3):108-109.

10. Ellenby, C. 1945. The influence of crucifers and mustard oil on the emergence of larvae of the potato root eelworm, Heterodera rostochiensis. Ann. App. Biol. 32:67-70.

11. Ellenby, G. 1945. Control of potato root eelworm, Heterodera rostochiensis, by allyl isothiocyanate, the mustard oil of Brassica nigra. Ann. Appl. Biol. 32:237-239.

12. Eno, C.F., H. G. Blue, and J. M. Good. 1955. The effects of anhydrous ammonia on nematodes, fungi, bacteria, and nitrification in some Florida soils. Soi Sci. Soc. Amer. $19(1): 55-58$. 
13. Esser, R. P., and E. K. Sobers, 1964. Natural enemies of nematodes. Proc. Soil and Crop. Sci. Soc. Fla, 24:326-353.

14. Jackson, M. L. 1958. Soil chemical analysis. Prentice-Hall, Inc. Englewood Cliffs, N. J. 498.pp.

15. Johnson, L. F. 1962. Effects of the addition of organic amendments to soil on root-knot of tomatoes. Il. Relation of soil temperatures, moisture and pH. Phytopathology 52:410-413.

16. Johnson, L. F., A. Y. Chambers, and H. E. Reed. 1967. Reduction of root-knot of tomato with crop residue amendments in field experiments. Plant Disease Reptr. 51(3):219-222.

17. Johnson, T. M. 1959. Effect of fatty acid mixtures on the rice stylet nematode (Tylenchorhynchus martini Fielding, 1956). Nature 183:1392.

18. Lear, B. 1959. Application of castor pomace and cropping of castor beans to soil to reduce nematode populations. Plant Disease Reptr. 43(4):459-460.

19. Linford, M. F., F. Yap, and J. M. 01iveira. 1938. Reduction of soil populations of the root-knot nematode during decomposition of organic matter. Soil Sci. 45:127-140.

20. Mankau, R. 1959. Nematode trapping fungi in Southern California citrus soils. Plant Disease Reptr. 43:968-969.

21. Mankau, R. 1960. The use of nematode trapping fungi to control root-knot nematodes. Phytopathology 50:645(Abstr.).

22. Mankau, R. 1961. An attempt to control root-knot nematodes with Dactylaria thaumasia and Arthrobotrys arthrobotryoides. Plant Disease Reptr. 45:164-166.

23. Mankau, R. 1961. The effect of some organic additives upon a soil nematode population and associated natural enemies. Nema tologica $7: 65-73$.

24. Mankau, R. 1963. Effect of organic soil amendments on nematode populations. Phytopathology 53:881-882(Abstr.).

25. Menzies, J. D. 1963. Survival of microbial plant pathogens in soil. Bot. Rev. 29:79-122.

26. Patrick, 7. A., and L. W. Koch, 1958. Inhibition of respiration, germination, and growth by substances arising during the decomposition of certain plant residues in the soil. Can. J. Botany $36: 621-646$. 
27. Patrick, Z. A., and L. W. Koch. 1963. The adverse influence of phytotoxic substances from decomposing plant residues on resistance of tobacco to black root rot. Can. J. Botany $41: 747-758$.

28. Patrick, Z. A., R. M. Sayre, and H. J. Thorpe. 1965. Nematocidal substances selective for plant-parasitic nematodes in extracts of decomposing rye. Phytopathology 55:702-703.

29. Patrick, Z. A., T. A. Toussoun, and W. C. Snyder. 1963. Phytotoxic substances in arable soils associated with decomposition of plant residues. Phytopathology 53:152-161.

30. Renninger, G., J. Coffey, and B. Sokoloff. 1958. Effect of hydrogenated fish oils on citrus tree destroying nematodes. Plant Disease Reptr. 42:1057-1065.

31. Sayre, R. M. Z. A. Patrick and H. J. Thorpe. 1965. Identification of a selective nematicidal component in extracts of plant residues decomposing in soil. Nenratologica 11:263-268.

32. Singh, R. S. 1964. Organic matter and biological control of plant parasitic nematodes. Uttar Pradesh, Agricultural University Magazine. 1963-64. 58-64.

33. Singh, R. S., B. Singh, and S. P. S. Beniwal. 1967. Observations on the effect of sawdust on incidence of root knot and on yield of okra and tomatoes in nematode-infested soil. Plant Disease Reptr. 51 (10):861-863.

34. Steiner, G. and Helen Heinly. 1922. The possibility of control of Heterodera radicicola and other plant-injurious nemas by means of predatory nemas, especially by Mononchus papillatus Bastian. J. Wash. Acad. Sci. 12(16):367-386.

35. Stolzy, L. H., S. D. Van Gundy, and J. Letey, Jr. 1960. Oxygen tolerances of four plant-parasitic nematodes. Phytopathology $50(9): 656$ (Abstr.).

36. Taylor, C. E., and A. F. Murant. 1966. Nematicidal activity of aqueous extracts from raspberry canes and roots. Nematologica $12: 488-494$.

37. Toussoun, T. A., and Z. A. Patrick. 1963. Effect of phytotoxic substances from decomposing plant residues on root rot of bean. Phytopathology 53(3):265-270.

38. Walker, J. T., C. H. Specht, and 5. Mavrodineau. 1967. Reduction of lesion nematodes in soybean meal and oil-anended soils. Plant Discase Reptr. 51 (3):1021-1024. 
39. Wallace, H. R. 1963. The biology of plant parasitic nematodes. Edward Arnold' (Publishers) Ltd., London. 280 pp. 


\section{BIOGRAPHICAL SKETCH}

Arthur Harris Tomerlin, Jr., was born November 10, 1941, at Homestead, Florida. He attended public school in Homestead, Florida, and was graduated in 1960 from South Dade High School in Homestead. He attended Dade County Junior College from 1960 to 1962 , and then transferred to the University of Florida. In June, 1964, he received the Bachelor of Science in Agriculture, and in April, 1966, he received the Master of Science degree. He continued graduate study, working toward the Doctor of Philosophy.

He is a member of Alpha Zeta, Phi Sigma, Gamma Sigma Delta, Sigma Xi, Newell Entonological Society, Helminthological Society of Washington and the Society of Nematologists.

He is married to the former Mireya M. Garcia and they have a daughter, Kathrine Maria. 
This dissertation was prepared under the direction of the chairman of the candidate's supervisory committee and has been approved by all members of that committee. It was submitted to the Dean of the College of Agriculture and to the Graduate Council, and was approved as partial fulfillment of the requirements for the degree of Doctor of Philosophy.

August, 1969

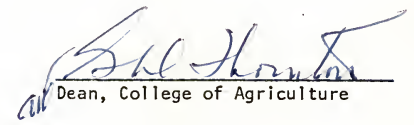

Dean, Graduate School

Supervisory Committee:
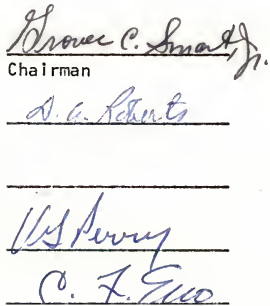